\title{
ResearchArticle
}

\section{Prevalence, symptomatology, pathogenicity and nutritional requirements of Fusarium oxysporum f.sp.phaseoli causing Fusarium yellows of French bean in Thandikudi}

\author{
S. ANUSUYA, M. MUTHAMILAN, N. REVATHY AND M. ANANTHAN
}

\begin{abstract}
SUMMARY
Fusarium yellows /wilt caused by Fusarium oxysporum f.sp.phaseoli are one of the serious diseases in French bean in Thandikudi and Kodaikanal hills of Dindugal district was found to prevalent in all French beans growing areas under survey with maximum of 71.25 per cent incidence and 65.88 per cent disease severity at Thandikudi village of Dindugal district in Tamil Nadu. The pathogenicity test was conducted by artificial inoculation of test fungus into the young two leaf stage of French bean and the typical symptom were produced after twelve days after inoculation. Among the different solid and liquid media tested oat meal agar potato dextrose agar medium supported growth of the casual fungus. Fungus could grow well at a $\mathrm{pH} 4.0$ and 5.0, respectively. This pathogenic fungus grew maximum when basal medium was supplemented with lactose and dextrose as carbon sources showed maximum growth and with potassium nitrate and sodium nitrate as nitrogen sources.
\end{abstract}

Key Words : Fusarium oxysporum f.sp.phaseoli, Pathogenecity, Thandikudi, Symptoms

How to cite this article : Anusuya, S., Muthamilan, M., Revathy, N. and Ananthan, M. (2016). Prevalence, symptomatology, pathogenicity and nutritional requirements of Fusarium oxysporum f.sp.phaseoli causing Fusarium yellows of French bean in Thandikudi. Internat. J. Plant Sci., 11 (2): 161-166, DOI: 10.15740/HAS/IJPS/11.2/161-166.

Article chronicle : Received : 02.02.2016; Revised : 03.04.2016; Accepted : 17.05.2016

\section{MEMBERS OF THE RESEARCH FORUM}

Author to be contacted :

S. ANUSUYA, Department of Plant Pathology, Agricultural College and Research Institute, MADURAI (T.N.) INDIA

Email: anusumanjushree@gmail.com

Address of the Co-authors:

M. MUTHAMILAN AND N. REVATHY, Department of Plant Pathology, Agricultural College and Research Institute, MADURAI (T.N.) INDIA

M. ANANTHAN, Department of Horticulture, Agricultural College and Research Institute, MADURAI (T.N.) INDIA 